\title{
Protocol
}

\section{Calling Card Analysis in Budding Yeast}

\author{
David Mayhew and Robi D. Mitra ${ }^{1}$ \\ Department of Genetics, Center for Genome Sciences and Systems Biology, Washington University School \\ of Medicine, St. Louis, Missouri 63110
}

Calling card analysis is a high-throughput method for identifying the genomic binding sites of multiple transcription factors in a single experiment in budding yeast. By tagging a DNA-binding protein with a targeting domain that directs the insertion of the Ty5 retrotransposon, the genomic binding sites for that transcription factor are marked. The transposition locations are then identified en masse by Illumina sequencing. The calling card protocol allows for simultaneous analysis of multiple transcription factors. By cloning barcodes into the Ty5 transposon, it is possible to pair a unique barcode with every transcription factor in the experiment. The method presented here uses expression of transcription factors from their native loci; however, it can also be altered to measure binding sites of transcription factors overexpressed from a plasmid.

It is essential that you consult the appropriate Material Safety Data Sheets and your institution's Environmental Health and Safety Office for proper handling of equipment and hazardous materials used in this protocol.

RECIPES: Please see the end of this protocol for recipes indicated by $<R>$. Additional recipes can be found online at http://cshprotocols.cshlp.org/site/recipes.

\section{Reagents}

Agarose gels (0.7\%) and running buffer

Barcoded Ty5 plasmid (pRM1001-series; $200 \mathrm{ng} / \mu \mathrm{L}$ )

These plasmids, which are available from the corresponding author, each contain an 8-bp barcode within the transposon that will be matched to each tagged strain.

Betaine (5 M)

BSA (20 mg/mL; molecular biology grade)

Carrier (Sheared Salmon Sperm) DNA Solution (10 mg/mL; Invitrogen)

Chloroform

$\mathrm{dH}_{2} \mathrm{O}$

dNTP mix (10 mm each of dATP, dCTP, dGTP, dTTP)

Ethanol (70\%, 100\%)

Galactose - Ura agar plates $<\mathrm{R}>$

Genomic DNA from yeast strain yRM1009

This strain is available from the corresponding author.

\footnotetext{
${ }^{1}$ Correspondence: rmitra@genetics.wustl.edu 
Glucose - His agar plates $<\mathrm{R}>$

Glucose - His 5-fluoroorotic acid (5-FOA) agar plates $<\mathrm{R}>$

Glucose - Ura medium $<\mathrm{R}>$

Glycerol (20\%; optional; see Step 16)

HindPI1 restriction enzyme and appropriate buffer

HpaII restriction enzyme and appropriate buffer

Lithium acetate $(1 \mathrm{M})$

Phenol:choloroform:isoamyl alcohol (PCA) (25:24:1)

Phusion DNA polymerase

Phusion HF buffer $(5 \times)$

Polyethylene glycol 3500 (PEG 3500; 50\% w/v)

Primers (all sequences are listed $5^{\prime}$ to $3^{\prime}$ )

"Forward" cloning primer: (N) ${ }_{40}$ AGAGTGTCGCATAGTGATAC

This primer includes $40 \mathrm{bp}$ upstream of the stop codon of the ORF of the DNA-binding protein of interest (without including the stop codon) plus $20 \mathrm{bp}$ to amplify the tagging domain.

"Reverse" cloning primer: $(\mathrm{N})_{40}$ CGCACTTAACTTCGCATCTG

This primer includes the reverse complement of the $40 \mathrm{bp}$ downstream from the ORF of the DNA-binding protein of interest (without including the stop codon) plus $20 \mathrm{bp}$ to amplify the tagging domain.

"Forward" inverse PCR primer: AATGATACGGCGACCACCGAGATCTACACTCTTTCCCTA CACGACGCTCTTCCGATCTAATTCACTACGTCAACA

"Reverse" inverse PCR primer: CAAGCAGAAGACGGCATACGAGATCGGTCTCGGCATTCC TGCTGAACCGCTCTTCCGATC

RedTaq DNA polymerase and associated buffer

RNaseA $(20 \mathrm{mg} / \mathrm{mL})$

Sodium acetate (3 $\mathrm{M}, \mathrm{pH} 5.2)$

TaqI restriction enzyme and appropriate buffer

T4 DNA ligase and associated buffer

Yeast calling card lysis buffer $<\mathrm{R}>$

Yeast strain of desired background

Strain must be deficient for SIR4, HIS3, and URA3 and sensitive to nourseothricin (NAT) antibiotic.

$\mathrm{YPD}<\mathrm{R}>$ (liquid medium and agar plates)

YPD agar plates with and without $100 \mu \mathrm{g} / \mathrm{mL}$ NAT are needed.

Equipment

Agarose gel apparatus

Centrifuge

Conical centrifuge tubes $(15-\mathrm{mL})$

Glass beads ( $0.2 \mathrm{~mm}$ diameter)

Glass culture tubes (5-mL; disposable)

Glass yeast spreader

Heat blocks

Incubator $\left(30^{\circ} \mathrm{C}\right)$

Microcentrifuge

Microcentrifuge tubes (1.5-mL)

Microcentrifuge tube rotator

PCR (polymerase chain reaction) tubes

QIAquick PCR purification kit (Qiagen)

Sequencing machine (Illumina GA, Illumina Miseq, or Illumina HiSeq with paired-end capabilities) 
Spectrophotometer for DNA quantification (Nanodrop [Thermo Scientific] or Qubit fluorometer [Invitrogen])

Thermocycler

Vacuum concentrator (e.g., Speedvac)

Velvet replica plating pads and base

Vortexer

Water bath

\section{METHOD}

\section{Cloning Strain}

This stage involves cloning the Ty 5 integrase-interacting domain of Sir4 to the carboxyl terminus of the desired TF. If the desired tagged strains have already been created, proceed to Step 11. See Figure 1 for an overview of the entire protocol.

1. Amplify the Sir4-NatR sequence from genomic DNA of strain yRM1009. Add the following PCR mix components and mix well:

$1 \times$ Phusion HF buffer

$0.5 \mu \mathrm{M}$ "forward" cloning PCR primer

$0.5 \mu \mathrm{M}$ "reverse" cloning PCR primer

$0.2 \mathrm{~mm}$ of each dNTP

1 unit Phusion DNA Polymerase

100 ng genomic DNA of yRM1009

$\mathrm{dH}_{2} \mathrm{O}$ to $50 \mu \mathrm{L}$

2. Perform the following cycling program:

\begin{tabular}{lcc} 
No. of cycles & Temperature & Time \\
\hline 1 & $98^{\circ} \mathrm{C}$ & $30 \mathrm{sec}$ \\
30 & $98^{\circ} \mathrm{C}$ & $10 \mathrm{sec}$ \\
& $58^{\circ} \mathrm{C}$ & $30 \mathrm{sec}$ \\
& $72^{\circ} \mathrm{C}$ & $2 \mathrm{~min}$ \\
1 & $72^{\circ} \mathrm{C}$ & $5 \mathrm{~min}$ \\
1 & $12^{\circ} \mathrm{C}$ & Hold
\end{tabular}

3. Run $5 \mu \mathrm{L}$ of the PCR product on $0.7 \%$ agarose gel using standard techniques to confirm success of PCR.

A single product at $1.8 \mathrm{~kb}$ is expected.

4. Inoculate the yeast strain of the desired background into $5 \mathrm{~mL}$ of YPD in a disposable $5-\mathrm{mL}$ glass culture tube. Grow to saturation overnight at $30^{\circ} \mathrm{C}$ with shaking. Dilute $50 \mu \mathrm{L}$ of the saturated starter culture into $5 \mathrm{~mL}$ YPD in a disposable $5-\mathrm{mL}$ glass culture tube. Grow at $30^{\circ} \mathrm{C}$ with shaking to an $\mathrm{OD}_{600}$ between 0.8 and $1.0(\sim 6 \mathrm{~h})$.

5. Pellet the cells by centrifuging the culture tube at $3000 \mathrm{rpm}$ for $2 \mathrm{~min}$ at room temperature. Remove the supernatant. Resuspend the cells in $1000 \mu \mathrm{L}$ of $\mathrm{dH}_{2} \mathrm{O}$ and transfer the cells to a microcentrifuge tube. Pellet the cells by centrifuging the tube at $10,000 \mathrm{rpm}$ for $2 \mathrm{~min}$ at room temperature. Remove the supernatant.

6. Add the following components of the transformation mix with the remaining PCR product from Step 3 directly on top of the pelleted cells to the following final concentrations and to a total volume of $360 \mu \mathrm{L}$ : 
A

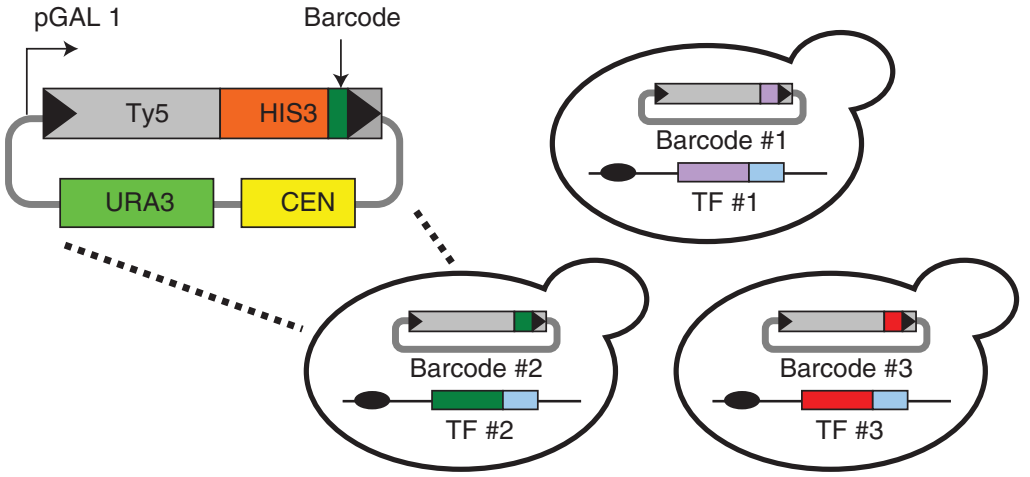

B

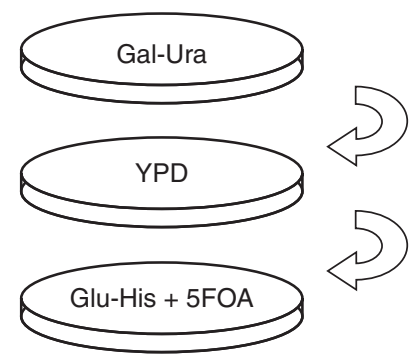

C

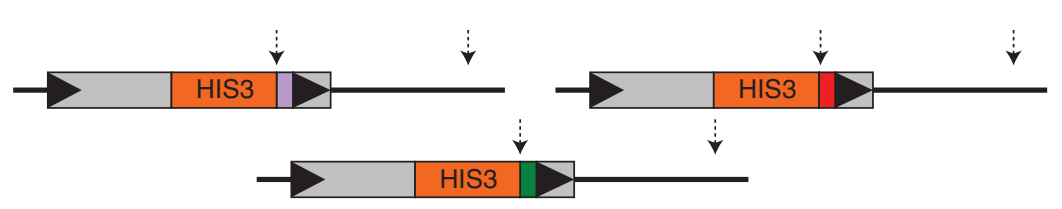

D
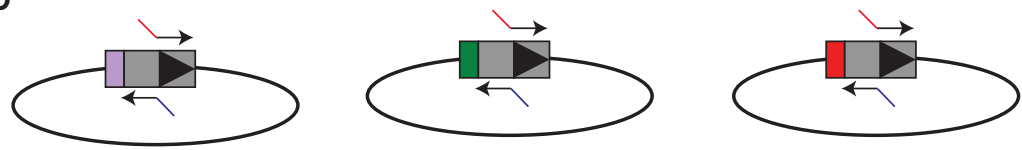

$\mathbf{E}$
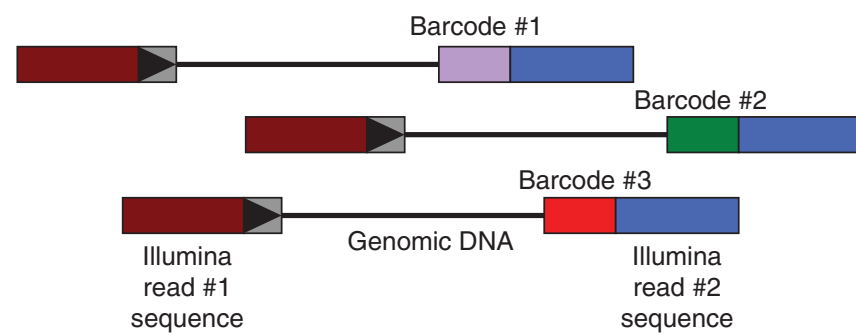

FIGURE 1. Overview of the calling card protocol. (A) Barcoded Ty 5 transposons are separately transformed into yeast strains with TFs tagged with Sir4. $(B)$ The strains are pooled, expression of Ty5 is induced, and the subsequent growth medium selects for genomic insertions. $(C)$ Genomic DNA is digested with restriction endonucleases. $(D)$ Digested fragments are self-ligated. $(E)$ Inverse PCR adds Illumina sequencing adaptors.

\begin{tabular}{lcc} 
Component & Amount (per reaction) & Final concentration \\
\hline PEG $3500(50 \% \mathrm{w} / \mathrm{v})$ & $240 \mu \mathrm{L}$ & $33.3 \%$ \\
Lithium acetate $(1 \mathrm{M})$ & $36 \mu \mathrm{L}$ & $0.1 \mathrm{M}$ \\
Carrier DNA solution & $10 \mu \mathrm{L}$ & $250 \mathrm{ng} / \mu \mathrm{L}$ \\
PCR product plus $\mathrm{dH}_{2} \mathrm{O}$ & $74 \mu \mathrm{L}$ &
\end{tabular}

7. Vortex the mixture and incubate in a water bath for $40 \mathrm{~min}$ at $42^{\circ} \mathrm{C}$.

8. Centrifuge the tube at $10,000 \mathrm{rpm}$ for $2 \mathrm{~min}$ at room temperature and remove supernatant. Resuspend the cell pellet in $1 \mathrm{~mL}$ of YPD and incubate with rotation for $60 \mathrm{~min}$ at $30^{\circ} \mathrm{C}$. 
9. Centrifuge the tube at 10,000 rpm for $2 \mathrm{~min}$ at room temperature and remove YPD. Resuspend

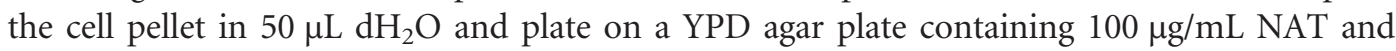
incubate for $2 \mathrm{~d}$ at $30^{\circ} \mathrm{C}$.

10. Select NAT resistant colonies and Sanger sequence the DNA bordering the tagged ORF to verify a correct clone.

Select at least three clones for each cloned strain.

\section{Plasmid Transformation and Induction}

This stage requires four different growth steps on separate days with $1 \mathrm{~h}$ of hands-on time each day.

11. Select a unique barcoded Ty5 donor plasmid for each transcription factor-tagged strain to be examined.

12. Separately inoculate each tagged strain from step 10 into $5 \mathrm{~mL}$ of YPD in a disposable 5 - $\mathrm{mL}$ glass culture tube. Grow to saturation overnight at $30^{\circ} \mathrm{C}$ with shaking. Dilute $50 \mu \mathrm{L}$ of the saturated starter culture into $5 \mathrm{~mL}$ YPD in a disposable $5-\mathrm{mL}$ glass culture tube. Grow at $30^{\circ} \mathrm{C}$ with shaking to an $\mathrm{OD}_{600}$ between 0.8 and $1.0(\sim 6 \mathrm{~h})$.

13. Pellet the cells by centrifuging the culture tube at $3000 \mathrm{rpm}$ for $2 \mathrm{~min}$ at room temperature. Remove the supernatant and wash cells as in Step 5.

14. For each tagged strain, add the following components of the transformation mix with a barcoded Ty5 plasmid to the following final concentrations and to a total volume of $360 \mu \mathrm{L}$ :

Component Amount (per reaction) Final concentration

\begin{tabular}{lrr}
\hline PEG $3500(50 \% \mathrm{w} / \mathrm{v})$ & $240 \mu \mathrm{L}$ & $33.3 \%$ \\
Lithium acetate $(1.0 \mathrm{M})$ & $36 \mu \mathrm{L}$ & $0.1 \mathrm{M}$ \\
Carrier (Sheared Sperm DNA Solution) & $10 \mu \mathrm{L}$ & $250 \mathrm{ng} / \mu \mathrm{L}$ \\
Ty5 plasmid $(200 \mathrm{ng} / \mu \mathrm{L})$ & $1 \mu \mathrm{L}$ & $0.6 \mathrm{ng} / \mu \mathrm{L}$ \\
$\mathrm{dH}_{2} \mathrm{O}$ & $73 \mu \mathrm{L}$ &
\end{tabular}

15. Vortex the mixture and incubate in a water bath for $40 \mathrm{~min}$ at $42^{\circ} \mathrm{C}$.

16. Centrifuge tube at $10,000 \mathrm{rpm}$ for $2 \mathrm{~min}$ at room temperature and remove the transformation mix. Resuspend the cell pellet in $50 \mu \mathrm{L}$ of $\mathrm{dH}_{2} \mathrm{O}$ and plate on a Glucose - His plate. Incubate at $30^{\circ} \mathrm{C}$ for $2 \mathrm{~d}$.

Transformed yeast can be frozen in $20 \%$ glycerol at $-80^{\circ} \mathrm{C}$ at this step to avoid repeating the previous steps in future experiments.

17. Inoculate a single colony from each barcoded-plasmid transformed strain in $5 \mathrm{~mL}$ of liquid Glucose - Ura medium in a disposable 5-mL glass culture tube. Grow to saturation overnight at $30^{\circ} \mathrm{C}$ with shaking. Pellet cells by centrifuging the culture tube at $3000 \mathrm{rpm}$ at room temperature for 2 min. Remove medium.

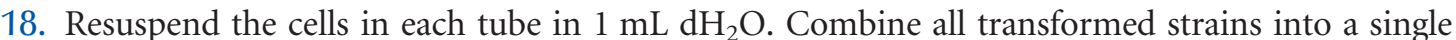
tube and mix well. Plate $100 \mu \mathrm{L}$ of this mixture onto each Galactose - Ura agar plate and incubate at room temperature for $2 \mathrm{~d}$.

Yeast should form a confluent lawn.

The Ty5 transposon is induced by galactose, so this is the step at which transcription factor binding is measured. If additional growth conditions are desired in the experiment, these should be supplied at this step. The number of Galactose - Uracil plates should scale with the number transcription factors being studied. As a rule of thumb, use two $10-\mathrm{cm}$ plates for each strain in the experiment (enough for $5 \times 10^{3}$ insertions), but DNA-binding proteins with a very large number of targets may require more plates to gather enough insertions to map all of their binding sites.

19. Replica plate cells to YPD agar plates by pressing the yeast-side of the Galactose - Ura agar plate to a clean velvet, removing, and then pressing a new YPD agar plate against the velvet. Use a clean velvet for each pair of plates. Incubate the plates for $1 \mathrm{~d}$ at $30^{\circ} \mathrm{C}$.

Yeast should form a confluent lawn. 
20. Replica plate cells from YPD plates to Glucose - His 5-FOA agar plates and incubate for $2 \mathrm{~d}$ at $30^{\circ} \mathrm{C}$.

This step selects for genomic insertions of Ty5 and counter-selects against cells still containing the plasmid. Each 10 -cm plate should have $\sim 2 \times 10^{3}$ colonies by the second day of growth.

See Troubleshooting.

DNA Extraction

Requires a total of $2 \mathrm{~h}$.

21. Pipette $1 \mathrm{~mL}$ of liquid YPD onto each Glu - His 5-FOA plate and scrape the yeast with a glass yeast spreader to put the cells into solution. Pipette the solution into a $15-\mathrm{mL}$ conical tube. Combine cells from different plates into a single conical tube. Mix by gently inverting the tube.

22. Transfer $500 \mu \mathrm{L}$ of the liquid mixture to a 1.5 - $\mathrm{mL}$ microcentrifuge tube. Centrifuge at $13,000 \mathrm{rpm}$ for $10 \mathrm{~min}$ at room temperature in a microcentrifuge and pour off the liquid.

23. To the pelleted cells add:

$400 \mu \mathrm{L}$ Yeast calling card lysis buffer

$400 \mu \mathrm{L}$ Glass beads (measure using a microcentrifuge tube)

$400 \mu \mathrm{L}$ Phenol:choloroform:isoamyl alcohol (25:24:1)

24. Vortex for $10 \mathrm{~min}$ at room temperature.

25. Centrifuge at $13,000 \mathrm{rpm}$ for $10 \mathrm{~min}$ at room temperature.

26. Transfer the aqueous supernatant to a new microcentrifuge tube.

27. Add $400 \mu \mathrm{L}$ of phenol:choloroform:isoamyl alcohol (25:24:1). Repeat Steps 24-26.

28. Add $400 \mu \mathrm{L}$ of chloroform. Repeat Steps 24-26.

29. Precipitate DNA by adding $40 \mu \mathrm{L}$ of 3 m sodium acetate and $1000 \mu \mathrm{L}$ of ethanol (100\%) at room temperature. Vortex and incubate for $60 \mathrm{~min}$ at $-70^{\circ} \mathrm{C}$.

30. Centrifuge at $13,000 \mathrm{rpm}$ for $10 \mathrm{~min}$ at room temperature. Carefully remove the supernatant.

31. Carefully wash the pellet with $500 \mu \mathrm{L}$ of ethanol (70\%) at room temperature.

32. Centrifuge at 13,000 rpm for $1 \mathrm{~min}$ at room temperature.

33. Remove ethanol supernatant with a micropipette and dry the pellet in a vacuum concentrator until all liquid is removed ( $\sim 10 \mathrm{~min})$. Reconstitute the pellet in $50 \mu \mathrm{L} \mathrm{dH}_{2} \mathrm{O}$ and $2 \mu \mathrm{L}$ RNaseA and incubate for $30 \mathrm{~min}$ at $37^{\circ} \mathrm{C}$.

At this step, genomic DNA can be frozen at $-20^{\circ} \mathrm{C}$ and stored long-term before subsequent steps.

\section{Genomic Digestions}

Requires a total of $3.5 \mathrm{~h}$.

34. Measure DNA concentration with a spectrophotometer.

35. Put $4 \mu \mathrm{g}$ of DNA into each of three PCR tubes. Perform the following three digestions in a total volume of $50 \mu \mathrm{L}$ each with the final concentrations and conditions as listed:

i. TaqI digestion

$$
\begin{aligned}
& 4 \text { Units TaqI enzyme } \\
& 1 \times \text { TaqI-compliant buffer } \\
& 1 \times \text { BSA }
\end{aligned}
$$

$\mathrm{dH}_{2} \mathrm{O}$ to $50 \mu \mathrm{L}$

Incubate for $3 \mathrm{~h}$ at $65^{\circ} \mathrm{C}$ followed by a heat inactivation for $20 \mathrm{~min}$ at $80^{\circ} \mathrm{C}$. 
D. Mayhew and R.D. Mitra

ii. HindPI1 digestion

4 Units HindPI1 enzyme

$1 \times$ HindPI1-compliant buffer

$\mathrm{dH}_{2} \mathrm{O}$ to $50 \mu \mathrm{L}$

Incubate for $3 \mathrm{~h}$ at $37^{\circ} \mathrm{C}$ followed by a heat inactivation for $20 \mathrm{~min}$ at $65^{\circ} \mathrm{C}$.

iii. HpaII digestion

4 units HpaII enzyme

$1 \times$ HpaII-compliant buffer

$\mathrm{dH}_{2} \mathrm{O}$ to $50 \mu \mathrm{L}$

Incubate for $3 \mathrm{~h}$ at $37^{\circ} \mathrm{C}$ followed by a heat inactivation for $20 \mathrm{~min}$ at $65^{\circ} \mathrm{C}$.

36. Purify digestions using the QIAquick PCR purification kit, following the manufacturer's protocol. Elute DNA in $50 \mu \mathrm{L}$ of $\mathrm{dH}_{2} \mathrm{O}$.

Self-Ligation

Requires a total of $14 \mathrm{~h}$ or overnight.

37. To each of the eluates from Step 36 add the reagents below to the following final concentrations:

18 units T4 ligase

$1 \times \mathrm{T} 4$ ligation buffer

$\mathrm{dH}_{2} \mathrm{O}$ to $400 \mu \mathrm{L}$

38. Incubate for at least $12 \mathrm{~h}$ at $14^{\circ} \mathrm{C}$.

Overnight incubation is preferable.

39. Precipitate DNA by following Steps 29-32.

40. Remove ethanol and dry the pellet in a vacuum concentrator. Resuspend the pellet in $50 \mu \mathrm{L}$ $\mathrm{dH}_{2} \mathrm{O}$ and vortex.

Requires a total of $4 \mathrm{~h}$.

41. Add the following PCR mix components to half $(25 \mu \mathrm{L})$ of each of the reconstituted DNA samples from Step 40 to yield the indicated concentrations:

$1 \times$ RedTaq PCR Buffer

$0.5 \mu \mathrm{M}$ "forward" inverse PCR primer

$0.5 \mu \mathrm{M}$ "reverse" inverse PCR primer

$0.2 \mathrm{~mm}$ of each dNTP

$0.5 \mathrm{~m}$ betaine

4 units RedTaq Enzyme

$\mathrm{dH}_{2} \mathrm{O}$ to $50 \mu \mathrm{L}$

42. Perform the following cycling program:

\begin{tabular}{lcc} 
No. of cycles & Temperature & Time \\
\hline 1 & $93^{\circ} \mathrm{C}$ & $2 \mathrm{~min}$ \\
30 & $93^{\circ} \mathrm{C}$ & $30 \mathrm{sec}$ \\
& $60^{\circ} \mathrm{C}$ & $6 \mathrm{~min}$ \\
1 & $12^{\circ} \mathrm{C}$ & Hold
\end{tabular}


43. Run $5 \mu \mathrm{L}$ of each PCR product on a $0.7 \%$ agarose gel using standard techniques to confirm the success of PCR.

Expect products ranging from $200 \mathrm{bp}$ to $2 \mathrm{~kb}$.

See Troubleshooting.

44. Purify PCR products using QIAquick PCR purification kit, following the manufacturers's protocol. Elute DNA in $50 \mu \mathrm{L}$ of $\mathrm{dH}_{2} \mathrm{O}$ and quantify the DNA concentration using Nanodrop/Qubit.

45. Combine equimolar quantities of the $3 \mathrm{PCR}$ products and dilute to $10 \mathrm{~nm}$ in $\mathrm{dH}_{2} \mathrm{O}$ for Illumina sequencing.

Assume an average PCR product size of $200 \mathrm{bp}$, which makes $10 \mathrm{~nm}$ equal to $1.32 \mathrm{ng} / \mu \mathrm{L}$. At least $20 \mu \mathrm{L}$ of the final solution is needed for Illumina sequencing.

46. Sequence the DNA on a paired-end Illumina sequencing run according to the manufacturer's instructions.

47. Analyze data by demultiplexing reads using the 8-bp barcode (the first eight bases on the second read), removing the first $17 \mathrm{bp}$ of the read (corresponds to the Ty5 transposon), and aligning the remaining bases of the read to the reference genome of the background yeast strain.

See Troubleshooting.

\section{TROUBLESHOOTING}

Problem (Step 20 or 47): A high background of yeast on the Glucose - Histidine + 5-FOA selection step or a high percentage of plasmid reads in the sequencing is observed.

Solution: The 5-FOA selection step is not killing all of the yeast still containing the Ty5 plasmid. An additional round of replica plating on Glucose - Histidine + 5-FOA plates will reduce plasmid in the extracted DNA.

Problem (Step 43): A thick band is observed at 100 bp with a smear of genomic DNA above this product.

Solution: Primer-dimers have formed during the inverse PCR. Perform a QIAquick gel extraction (QIAGEN) to separate the larger products from the primer-dimer size fragments before sequencing.

\section{DISCUSSION}

Chromatin immunoprecipitation read out by either microarrays (ChIP-chip) (Horak and Snyder 2002) or next-generation sequencing (ChIP-seq) (Johnson et al. 2007) has been an invaluable technique for identifying the binding sites of transcription factors (TFs) in yeast. For studies requiring large numbers of TFs, the nature of ChIP-based methods requires increased time and work for each additional TF in the experiment. Large sequencing capacities of next-generation sequencers allow for ChIP-seq libraries of many TFs to be barcoded and sequenced in parallel (Lefrançois et al. 2009); however, the immunoprecipitation for each TF is performed independently. This limitation makes large-scale ChIP experiments laborious. The ability of the calling card technique to multiplex many TFs through most of the steps in this protocol makes scaling up these experiments more feasible.

The number of TFs that can be included in this protocol is a function of the downstream sequencing capacity. To ensure adequate coverage of all of the insertions with each barcode, $1-2 \times$ $10^{6}$ reads are required for each barcode/TF included in the multiplex. Experiments with large numbers of TFs may make the growth and selection steps on solid plates unsuitable. For these larger experi- 
ments the protocol can be altered to move these steps (18-20) to liquid cultures. For more information on the data analysis or altering the protocol to overexpress the TF-Sir4 fusion from a plasmid, please see Wang et al. (2011).

A limitation of calling cards is that there are currently fewer existing yeast strains with TFs tagged for the method compared with ChIP-ready tagged strains. The study of some TFs or background strains will necessitate cloning them as described in the first steps of this protocol. The method is easy to use and provides high signal-to-noise mapping of DNA-binding with an accuracy and resolution comparable with ChIP-seq (Wang et al. 2011). This protocol should be adaptable to many experiments for mapping binding sites of DNA-binding proteins, especially when multiple proteins need to be studied.

\section{RECIPES}

\section{Drop-Out Mix}

Reagent

Adenine

Alanine

Arginine

Asparagine

Aspartic acid

Cysteine

Glutamine

Glutamic acid

Glycine

Histidine

Inositol

Isoleucine

Leucine

Lysine

Methionine

para-Aminobenzoic acid

Phenylalanine

Proline

Serine

Threonine

Tryptophan

Tyrosine

Uracil

Valine
Amount to add

$$
0.5 \mathrm{~g}
$$

$2.0 \mathrm{~g}$

$2.0 \mathrm{~g}$

$2.0 \mathrm{~g}$

$2.0 \mathrm{~g}$

$2.0 \mathrm{~g}$

$2.0 \mathrm{~g}$

$2.0 \mathrm{~g}$

$2.0 \mathrm{~g}$

$2.0 \mathrm{~g}$

$2.0 \mathrm{~g}$

$2.0 \mathrm{~g}$

$10.0 \mathrm{~g}$

$2.0 \mathrm{~g}$

$2.0 \mathrm{~g}$

$0.2 \mathrm{~g}$

$2.0 \mathrm{~g}$

$2.0 \mathrm{~g}$

$2.0 \mathrm{~g}$

$2.0 \mathrm{~g}$

$2.0 \mathrm{~g}$

$2.0 \mathrm{~g}$

$2.0 \mathrm{~g}$

$2.0 \mathrm{~g}$

Combine the appropriate ingredients, in $1 \mathrm{~L}$ of medium minus the relevant supplements, and mix in a sealed container. Turn the container end-over-end for at least $15 \mathrm{~min}$; add several clean marbles to help mix the solids.

\section{Galactose - Ura Agar Plates}

$1.7 \mathrm{~g} \quad$ Yeast nitrogen base without amino acids and ammonium sulfate

$1 \mathrm{~g} \quad$ Dropout mix (without uracil) $<\mathrm{R}>$

$5 \mathrm{~g} \quad$ Ammonium sulfate

$20 \mathrm{~g} \quad$ Agar

Add $\mathrm{H}_{2} \mathrm{O}$ to $900 \mathrm{~mL}$, stir well, and autoclave. Add $100 \mathrm{~mL}$ of $20 \%$ galactose (sterile) and stir. Pour into sterile Petri dishes and allow to solidify. 


\section{Glucose - His Agar Plates}

$1.7 \mathrm{~g} \quad$ Yeast nitrogen base without amino acids and ammonium sulfate

$1 \mathrm{~g} \quad$ Drop-out mix (without histidine) $<\mathrm{R}>$

$5 \mathrm{~g} \quad$ Ammonium sulfate

$20 \mathrm{~g} \quad$ Agar

Add $\mathrm{H}_{2} \mathrm{O}$ to $900 \mathrm{~mL}$, stir well, and autoclave. Add $100 \mathrm{~mL}$ of $20 \%$ glucose (sterile) and stir. Pour into sterile Petri dishes and allow to solidify.

\section{Glucose - His 5-Fluoroorotic Acid (5-FOA) Agar Plates}

$1.7 \mathrm{~g} \quad$ Yeast nitrogen base without amino acids and ammonium sulfate

$1 \mathrm{~g} \quad$ Drop-out mix (without histidine) $<\mathrm{R}>$

$5 \mathrm{~g} \quad$ Ammonium sulfate

$20 \mathrm{~g} \quad$ Agar

Add $\mathrm{H}_{2} \mathrm{O}$ to $900 \mathrm{~mL}$, stir well, and autoclave. Add $100 \mathrm{~mL}$ of $20 \%$ glucose (sterile) and 1 g 5-FOA, and stir. Pour into sterile Petri dishes and allow to solidify.

\section{Glucose - Ura Medium}

$1.7 \mathrm{~g} \quad$ Yeast nitrogen base without amino acids and ammonium sulfate

$1 \mathrm{~g} \quad$ Drop-out mix (without uracil) $<\mathrm{R}>$

$5 \mathrm{~g} \quad$ Ammonium sulfate

Add $\mathrm{H}_{2} \mathrm{O}$ to $900 \mathrm{~mL}$, stir well, and autoclave. Add $100 \mathrm{~mL}$ of $20 \%$ glucose (sterile) and stir. Store for up to $3 \mathrm{mo}$ at $4^{\circ} \mathrm{C}$.

Yeast Calling Card Lysis Buffer

2\% Triton X-100

$1 \%$ SDS

$100 \mathrm{~mm} \mathrm{NaCl}$

10 mm Tris- $\mathrm{HCl}(\mathrm{pH} 8.0)$

1 mм EDTA (pH 8.0)

Store for up to $12 \mathrm{mo}$ at $4^{\circ} \mathrm{C}$.

$Y P D$

Peptone, $20 \mathrm{~g}$

Glucose, $20 \mathrm{~g}$

Yeast extract, $10 \mathrm{~g}$

$\mathrm{H}_{2} \mathrm{O}$ to $1000 \mathrm{~mL}$

YPD (YEPD medium) is a complex medium for routine growth of yeast.

To prepare plates, add $20 \mathrm{~g}$ of Bacto Agar (2\%) before autoclaving.

\section{REFERENCES}

Horak CE, Snyder M. 2002. ChIP-chip: A genomic approach for identifying transcription factor binding sites. Methods Enzymol 350: 469-483.

Lefrançois P, Euskirchen GM, Auerbach RK, Rozowsky J, Gibson T, Yellman CM, Gerstein M, Snyder M. 2009. Efficient yeast ChIP-Seq using multiplex short-read DNA sequencing. BMC Genomics 10: 37.
Johnson DS, Mortazavi A, Myers RM, Wold B. 2007. Genome-wide mapping of in vivo protein-DNA interactions. Science 316: 1497-1502.

Wang H, Mayhew D, Chen X, Johnston M, Mitra RD. 2011. Calling Cards enable multiplexed identification of the genomic targets of DNAbinding proteins. Genome Res 5: 748-755. 


\section{Calling Card Analysis in Budding Yeast}

David Mayhew and Robi D. Mitra

Cold Spring Harb Protoc; doi: 10.1101/pdb.prot086918

\begin{tabular}{rc}
$\begin{array}{r}\text { Email Alerting } \\
\text { Service }\end{array}$ & Receive free email alerts when new articles cite this article - click here. \\
\hline $\begin{array}{c}\text { Subject } \\
\text { Categories }\end{array}$ & Browse articles on similar topics from Cold Spring Harbor Protocols. \\
& Cloning By PCR (30 articles) \\
& DNA Sequencing (96 articles) \\
& DNA:Protein Interactions (74 articles) \\
& Genome Analysis (191 articles) \\
& Polymerase Chain Reaction (PCR) (139 articles) \\
& Transgenic Technology, general (187 articles) \\
& Yeast (288 articles) \\
& Yeast Genetics (135 articles) \\
\hline
\end{tabular}

